A. Splodytel, PhD (Geogr.), E-mail: asplodytel@gmail.com; M.P. Semenenko Institute of Geochemistry, Mineralogy and Ore Formation of the NAS of Ukraine, 34 Acad. Palladina Ave., Kyiv, 03680, Ukraine

\title{
ECOLOGICAL AND GEOCHEMICAL ESTIMATION OF THE SPREADING OF TECHNOGENIC ELEMENTS IN THE TERRITORY OF KIVERTSIV NATIONAL NATURAL PARK "TSUMANSKA PUSHCHA"
}

(Представлено членом редакційної колегї д-ром геол. наук, доц. С.Є. Шнюковим)

Analysis of heavy metals content in the soils of the territory showed its heterogeneous distribution and dependence on available sources of technogenic impact. Geochemical accumulation coefficients were calculated and analyzed. The highest concentrations of manganese and chromium are in soils developed on forest deposits. The highest concentrations of nickel and copper are in soils developed on water-glacial deposits. Most of the studied heavy metals exceed the regional geochemical background. In terms of gross content in soils, trace elements form the following geochemical series: $\mathrm{Zn}>\mathrm{Cu}>\mathrm{Pb}>\mathrm{Ni}>\mathrm{Mn}>\mathrm{Cr}$. Accumulation of lead in forest deposits up to 2-3 MPC was defined.

Most heavy metals in the soil are nonuniformity distributed. High values of the variation coefficient (V) - more than $34 \%$ - are typical for inhomogeneous set of data on the concentrations of all investigated heavy metals. The highest index of variation was defined for lead concentration and equal to $170 \%$, the lowest values were obtained for chromium content and equal to $34 \%$ and zinc - $36 \%$. In the investigated soils there are two types of micronutrient distribution: elements accumulation in organic horizons with concentration decrease in the lower part of the profile and distribution by sedentary-illuvial type. The first type is characterized by increasing distribution of the following elements $\mathrm{Zn}, \mathrm{Pb}$; the second one is characterized $\mathrm{Co}, \mathrm{Ni}, \mathrm{Cu}, \mathrm{Mn}$.

The ecological and geochemical assessment of technogenic elements distribution of the NNP Tsumanska Pushcha territory is made on the basis of the comparison of technogenic geochemical specialization of different environments (water, soils, etc.). For assessing the role of landscape components in the general geochemical anomaly of the territory, it is proposed to create total ecological and geochemical estimations. It represents the total values of pollutant concentration coefficients in individual components.

Further researchers should focus on the analysis of macronutrients and genetic types of soils; determination of the reference content of elements in geochemical landscapes for defining intensity migration and characteristics of elements distribution; conducting biogeochemical zoning.

Keywords: gross content, technogenic elements, accumulation coefficients.

Introduction. The study of the regularities of mobilization and migration of heavy metals in soils of natural ecosystems is one of the urgent scientific problems. At the moment, the ecologic and geochemical research in the conditions of anthropogenesis is generally based on studying gross elements content distribution. The research problem of forms of toxic elements locations in soils and bottom sediments stays insufficiently investigated. This refers to nature preserve territories of Polissia, where geoecological research of such a kind practically has not been carried out. Meanwhile, in the conditions of anthropogenesis, many chemical elements qualitatively change natural geochemical forms of migration into more movable, easily dissolving, and accessible for plants. These data are necessary to conduct ecological and geochemical monitoring, ecological mapping, etc.

The objective of the article is to discover the specificity of chemical elements distribution and accumulation in soil formation rocks and soils on the territory of Kivertsi National Nature Park "Tsumanska Pushcha".

The primary study tasks:

1. To examine the specificity of general chemical elements distribution in soil formation rocks and soils;

2. To study forms of microelements location in current bottom sediments in the rivers of Kivertsi National Nature Park "Tsumanska Pushcha";

3. To research specificity of vertical accumulation of heavy metals according to genetic horizons of soils which are most typical for National Nature Park;

4. To conduct an analysis of forms of heavy metals location in soils on the territory and identify their contamination sources.

Analysis of the recent studies and publications. Studies of the geoecological conditions of soil covering of the territory have been carried out in the scope of complex research of natural conditions of Volyn Polissia. In the framework of aforementioned studies, Kivertsivskyi National Nature Park "Tsumanska Pushcha" has been created. One of the first complex research on Volyn landscapes is P.A. Tutkovskyi's works $(1913,1924)$. In the works of V.S. Havryliuk (1955), P.V. Klymovych (1961), K.I. Herenchuk (1966), regularities of landscape and geochemical composition of Volyn Polissia are discussed, and the results of studies on soils change because of water melioration of overmoistened Polissia lands are presented. Anthropogenic transformation of West Polissia landscape was studied by I.B. Koinova (1999), N.A. Tarasiuk and F.P. Tarasiuk (2005); analysis of the ecological and economic organization of Volyn Region landscape in terms of their functional purpose was conducted by O.V. Mishchenko (2016).

In 60-70's, the studies of elements movable forms distribution in various regions across Ukraine were conducted by P.A. Vlasiuk, N.K. Krupskyi, A.M. Aleksandrova, R.N. Benderskyi, A.M. Bilan, Yu.M. Labii. In 80-90's, the studies of forms of heavy metals location in Ukrainian soils are carried out by scientists under the leadership of E.Ya. Zhovynskyi, A.I. Samchuk, H.M. Belonenko, V.I. Pochtarenko, N.M. Horodnii and others.

The specific features of accumulation and migration of gross and movable forms of microelements in soils are described in studies of international scholars (Bascomb, Berti, Bloom, Filgueiras, Hlavay, Kersten, McLaren, Mikutta, Mitchell, Papp, Rauret, Salomons, Sedberry, Shuman, Tessier, Ure, etc.)

Though, studies of specificities of distribution and accumulation of chemical elements in soil formation rocks and soils on the territory of Kivertsi National Nature Park "Tsumanska Pushcha" as an independent object of studies, have not been carried out before.

Materials and methods of the research. We used the factual material of field landscape science and geochemical surveys carried out in summer-autumn period of 2018-2019. During the field researches about 130 rock samples and more than 1200 soil samples were taken. Total number of biogeochemical samples of the main plants of the NNP is more than 640 samples.

Sampling of soil samples was carried out by "envelope" method from plots of $10 \times 10 \mathrm{~m}$. The following list of works was carried out on each sampling plot:

- geographical coordinates by GPS were determined;

- the category of nature use was defined;

○ Splodytel A., 2021 
- description of vegetative cover is formed;

- soil sections are laid;

- a morphological description of soils is performed;

- sampling was carried out for genetic bedding rocks of the soil profile and impure soil samples for chemical analysis in laboratory conditions.

HM content was determined by mass spectral (ICP-MS) and atomic emission methods (ICP-AES) with inductively coupled plasma on Elan-6100 devices and ICP-MS analyzer ELEMENT-2, (made in Germany) at the M.P. Semenenko Institute of Geochemistry, Mineralogy and Ore Formation NASU and Institute of Geology of Polish Academy of Sciences.

As a result of carried out work, a series of poly element maps at the scale of 1:50,000 was concluded, which served as the basis for studying the spreading of heavy metals in soil and vegetation cover also establishing the effect of natural and man-made migration factors on them. To compile thematic maps of the spatial spreading of heavy metals at the soil in terms of Zc total pollution, obtained data were interpolated using the ArcGIS ArcMap software package by using the Kriging method.

Chemical elements spreading in soil-forming rocks. Water-glacial and alluvial sediments dominate among the soil-forming rocks of the NNP territory. Of greatest interest are data on the chemical composition of glacial sands. Average content is (in \%): $\mathrm{SO}_{2}-72,83, \mathrm{~A}_{2} \mathrm{O}_{3}-4,10, \mathrm{Fe}_{2} \mathrm{O}_{3}-$ $0,82, \mathrm{FeO}-0,18, \mathrm{TiO}_{2}-0,18, \mathrm{CaO}-1,78, \mathrm{MgO}-0,68$, $\mathrm{K}_{2} \mathrm{O}-1,67, \mathrm{Na}_{2} \mathrm{O}-0,64$.

Modern alluvial deposits are represented by channel oblique and horizontally stratified sands in some places with gravel admixtures of underlying bedrock with an average thickness of 3-5 m (watercourse alluvium), as well as sands and loams, with clear horizontal layering, often peated (channel margin sand). Capacity of the channel margin sand reaches 5-6 $\mathrm{m}$ and more. Sandy loam and uliginous aggradations are most common in the valley of the Putylivka and Kormyn rivers. Among the aggradations of the channel margin sands, in addition to fine sands, there are lenses of coarse-grained sand, gravel, and pebbles.

According to the results of our research, the alluvial aggradations of Rudka river floodplain are characterized by predominance of particles of $0.5-0.05 \mathrm{~mm}$, which is $98 \%$. The granulometric spectrum of floodplain sediments is characterized by presence of particles $>1.0 \mathrm{~mm}$ on average $1.55 \%$; 1.0 $0.2 \mathrm{~mm}-41.34 \%$; 0.10-0.01 mm - 47.69\% and $<0.01 \mathrm{~mm}-$ $6.21 \%$. The median particle size ranges from $0.008-0.34 \mathrm{~mm}$ and the value of the sorting coefficient is 1.46-2.87. According to results of the research, about 35-40 minerals were found in the floodplain of alluvium. Composition of the main of them is fractions of $0.25-0.05$ and $0.05-0.01 \mathrm{~mm}$ on average, respectively (\%): quartz 84.6 and 66.3 , feldspar 11.9 and 12.5 , biotite in the first fraction 16.8; among heavy minerals are ilmenite with magnetite 19.8 and 20.2 , amphibole 33.0 and 44.5 , garnets 15.3 and 8.4 , tourmaline 2.6 and 1.4 , zircon 1.4 and 2.4 . There are also limonite, leucoxene, hypersthene, chlorite, rutile, apatite, biotite, and other minerals. Alluvium of the floodplain-terrace plain has similar data on granulometric and mineralogical composition.

Sands of the modern river alluvium of the Rudka river contain (\%): $\mathrm{SiO}_{2}-94.03, \mathrm{Fe}_{2} \mathrm{O}_{3}-0.04, \mathrm{FeO}-0.41, \mathrm{Al}_{2} \mathrm{O}_{3}-$ 2.95, $\mathrm{CaO}-0.89, \mathrm{MgO}-0.62, \mathrm{CO}_{3}-0.09, \mathrm{Na}_{2} \mathrm{O}-0.72$, $\mathrm{K}_{2} \mathrm{O}-1.43, \mathrm{CO}_{2}-0.51$, sludge $-\mathrm{SiO}_{2}-61.13, \mathrm{Fe}_{2} \mathrm{O}_{3}-5.67$, $\mathrm{FeO}-2.97, \mathrm{Al}_{2} \mathrm{O}_{3}-5.12, \mathrm{TiO}_{2}-0.31, \mathrm{CaO}-0,52, \mathrm{MgO}-$ $0.35, \mathrm{SO}_{3}-3.18, \mathrm{Na}_{2} \mathrm{O}-0.29, \mathrm{~K}_{2} \mathrm{O}-0.93$. Floodplain sands of the river Kormyn contain: (\%) $\mathrm{SiO}_{2}-92.64-93.15, \mathrm{Al}_{2} \mathrm{O}_{3}-$ $1.93-2.45, \mathrm{Fe}_{2} \mathrm{O}_{3}-0.22-0.36, \mathrm{TiO}_{2}-0.04-0.27, \mathrm{Na}_{2} \mathrm{O}-$ $0.45-0.87, \mathrm{~K}_{2} \mathrm{O}-1.32-1.87, \mathrm{CaO}-0.11-0.56, \mathrm{MgO}-0.12-$ $0.23, \mathrm{P}_{2} \mathrm{O}_{5}-0.24-0.29$
The concentrations of microelements fluctuate depending on the lithological type of aggradations, their facies and localization in the river basin. Content of nickel, cobalt, lead, chromium, vanadium, manganese and copper, although characterized by significant deviations from the average concentrations, however, does not exceed their calculated anomalous values. At the same time, in relation to the composition of microelements in modern channel sands in general, the alluvium of the river Kormyn is characterized by high concentrations of $\mathrm{SiO}_{2}, \mathrm{Al}_{2} \mathrm{O}_{3}$, and $\mathrm{Fe}_{2} \mathrm{O}_{3}$. This is due to the lithological and geochemical characteristics of the rocks of the territory, as well as to the significant swampiness of the landscapes of the territory.

The alluvial deposits of the NNP, in comparison with the average values for the alluvial aggradations of protected areas as a whole, have increased concentrations of titanium, chromium, nickel, copper and manganese.

In the alluvial aggradations of the valleys of the rivers Rudka, Kormin contains $(\mathrm{n} \times 10-3 \%) \mathrm{Be}-0.1-0.5, \mathrm{Mn}-2-68$, $\mathrm{Pb}-0.6-1.3, \mathrm{Ga}-0.5-8,2, \mathrm{~V}-1.4-6.8, \mathrm{Ni}-0.6-7.1$, Ba 1.5-12 and $\mathrm{Cr}-1.8-11.5$.

The content of amorphous oxides of iron, aluminum, manganese and silicon in modern river deposits of the park as a whole is characterized by close values of concentrations characteristic of sands and silt of the territory of Ukrainian Polissya. The highest concentrations of amorphous forms of chemical elements are characteristic of mules, the lowest - for channel sands.

In order to determine the migration forms of chemical elements in the river network of NNP, their accumulation, as well as reserves for assimilation by plants, the forms of finding of microelements in river bottom sediments, represented by fine-grained sands containing increased amounts of silty biogenic substances, were studied. Forms of migration are determined by the method of step-by-step extracts, by method of H.A. Shymko, V.A. Kuznyetsovaa (Zhovynskyi et al., 2005, 2012; Adriano, 1986; Stoops at al., 2010).

As we can see from table 1, cobalt, vanadium, titanium are not found in extracts of water-soluble components and easily exchangeable ions, indicating their weak migration in easily mobile forms. Copper in the form of water-soluble components migrates to a small extent, but locally reaches $25.5 \%$ of the gross content, and in the form of easily exchangeable ions from 3.6 to $21.5 \%$. Manganese as the most mobile trace element in wetlands in the first form is $0.06-0.15 \%$ and in the second - from 1.72 to $12.28 \%$ of the gross content.

Elements associated with carbonates are extracted in different ways. Cobalt is detected locally in the amount of $51-57 \%$ of the gross content. Copper in the extract was not found. Vanadium is contained in the range of 1.62-5.72\%, and manganese $-7.32-68.15 \%$ of gross, indicating their reserves of active migration in conditions of changes in $\mathrm{pH}$, temperature and carbon dioxide, causing the dissolution of carbonates or their falling out of solution. Titanium is found in small quantities - from small traces to $0.06 \%$.

Characteristic connections of the studied trace elements with organic matter are noticeable. Some trace elements are constantly present in the composition of amorphous hydroxides, excluding cobalt and vanadium, which were not found here, manganese as satellite of iron - in the conditions of the reserved zone of the park, this form migrates only in quantities of $0.76-2.81 \%$ of the total content.

Titanium is concentrated in hard-destroying minerals, accounting for $78.62-93.67 \%$ of the gross content in insoluble sludge and only $4.82-12.51 \%$ in easily-destroying silicates, which indicates a relatively weak migration with river waters. High concentrations in the insoluble sediment are also typical for manganese $-25.67-84.58 \%$, vanadium 14.11-61.56, copper - 8.12-67.72\%. The bulk of cobalt in some places belongs to easily destructive silicates. 
Forms of occurrence of trace elements in modern bottom sediments of rivers NNP

Table 1

\begin{tabular}{|c|c|c|c|c|c|c|c|c|}
\hline \multirow[b]{2}{*}{$\begin{array}{c}\text { № } \\
\text { points }\end{array}$} & \multirow[b]{2}{*}{ Location } & \multicolumn{7}{|c|}{ Extracts, $\mathbf{m g} / \mathbf{k g}$} \\
\hline & & 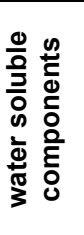 & 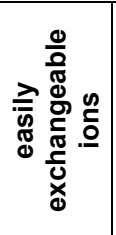 & 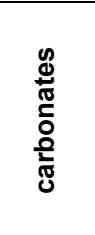 & 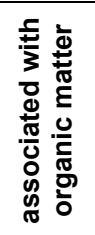 & 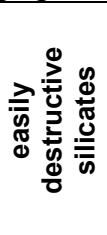 & 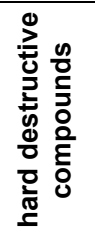 & 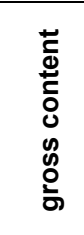 \\
\hline & & \multicolumn{6}{|c|}{ Copper } & \\
\hline $16-19$ & Floodplain, river Rudka, Q. 4 APC & 2.06 & 0.61 & - & 4.87 & 0.8 & 1.6 & 11.5 \\
\hline $19-19$ & Quarter -6 near the lake, quarry & - & 2.76 & - & 7.32 & 0.73 & 0.89 & 12.0 \\
\hline $22-19$ & Floodplain of the river Rudka, $50 \mathrm{~m}$ from the riverbed & 2.03 & 0.67 & - & 6.34 & - & 2.1 & 8.7 \\
\hline $30-19$ & Floodplain of the river Rudka, collecting channel & - & 2.45 & - & 7.12 & 0.72 & 0.91 & 13 \\
\hline $45-19$ & Starytsia and river Kormyn & - & 1.07 & - & 3.95 & 2.1 & 11.5 & 18 \\
\hline \multirow[t]{2}{*}{$52-19$} & Floodplain of the river Kormin, marginal part & - & 0.54 & - & 4.11 & 0.41 & 1.8 & 4.6 \\
\hline & & \multicolumn{6}{|c|}{ Manganese } & \\
\hline $16-19$ & Floodplain, river Rudka, Q. 4 APC & 0.16 & 12.32 & 198.8 & 21.17 & 10.34 & 123.7 & 357 \\
\hline $19-19$ & Quarter - 6 near the lake, quarry & 0.02 & 4.78 & 62.4 & 23.5 & 3.1 & 65.4 & 132.5 \\
\hline $22-19$ & Floodplain of the river Rudka, $50 \mathrm{~m}$ from the riverbed & 0.01 & 3.05 & 15.13 & 5.11 & 3.45 & 72.58 & 101.5 \\
\hline $30-19$ & Floodplain of the river Rudka, collecting channel & 0.13 & 1.86 & 9.10 & 3.16 & 4.87 & 79.5 & 97.8 \\
\hline $45-19$ & Starytsia and river Kormyn & 0.11 & 11.23 & 223.7 & 52.12 & 18.6 & 134.7 & 375.7 \\
\hline \multirow[t]{2}{*}{$52-19$} & Floodplain of the river Kormin, marginal part & 0.01 & 4.7 & 39.53 & 18.65 & 1.7 & 64.3 & 126.7 \\
\hline & & \multicolumn{6}{|c|}{ Titanium } & \\
\hline $16-19$ & Floodplain, river Rudka, Q. 4 APC & - & - & - & 0.9 & 95.8 & 369.5 & 1670 \\
\hline $19-19$ & Quarter -6 near the lake, quarry & - & - & 0.07 & 19.02 & 39.4 & 390.8 & 410.7 \\
\hline $22-19$ & Floodplain of the river Rudka, $50 \mathrm{~m}$ from the riverbed & & & 0.19 & 32.46 & 53.8 & 401.6 & 390.5 \\
\hline $30-19$ & Floodplain of the river Rudka, collecting channel & - & - & - & 10.11 & 41.24 & 504.2 & 592.5 \\
\hline $45-19$ & Starytsia and river Kormyn & - & - & - & 5.34 & 62.1 & 864.2 & 820 \\
\hline \multirow[t]{2}{*}{$52-19$} & Floodplain of the river Kormin, marginal part & - & - & - & 16.7 & 91.5 & 1250 & 1540 \\
\hline & & \multicolumn{6}{|c|}{ Cobalt } & \\
\hline $16-19$ & Floodplain, river Rudka, Q. 4 APC & - & - & 0.70 & 0.09 & 0.39 & - & 1.1 \\
\hline $19-19$ & Quarter - 6 near the lake, quarry & - & - & - & - & 0.28 & - & 0.3 \\
\hline $22-19$ & Floodplain of the river Rudka, $50 \mathrm{~m}$ from the riverbed & - & - & - & 0.19 & 0.16 & - & 0.38 \\
\hline $30-19$ & Floodplain of the river Rudka, collecting channel & - & - & - & 0.22 & 0.15 & - & 0.40 \\
\hline $45-19$ & Starytsia and river Kormyn & - & - & 0.89 & 0.42 & 0.35 & 14.2 & 16.5 \\
\hline \multirow[t]{2}{*}{$52-19$} & Floodplain of the river Kormin, marginal part & - & - & - & - & 0.05 & - & 0.05 \\
\hline & & \multicolumn{6}{|c|}{ Vanadium } & \\
\hline $16-19$ & Floodplain, river Rudka, Q. 4 APC & - & - & 0.65 & 2.52 & 2.46 & 3.77 & 9.2 \\
\hline $19-19$ & Quarter -6 near the lake, quarry & - & - & 0.54 & 3.83 & 2.11 & 1.78 & 7.2 \\
\hline $22-19$ & Floodplain of the river Rudka, $50 \mathrm{~m}$ from the riverbed & - & - & 1.32 & 15.32 & 1.42 & 2.61 & 19.8 \\
\hline $30-19$ & Floodplain of the river Rudka, collecting channel & - & - & 0.27 & 3.76 & 0.75 & 2.89 & 7.4 \\
\hline $45-19$ & Starytsia and river Kormyn & - & - & 0.86 & 5.67 & 2.42 & 10.62 & 21.15 \\
\hline $52-19$ & Floodplain of the river Kormin, marginal part & - & - & 0.31 & 13.43 & 1.28 & 2.59 & 15.8 \\
\hline
\end{tabular}

Concentrations of copper, vanadium, manganese in this form are insignificant, they generally do not exceed $10 \%$, with the exception of individual local samples. Thus, according to the study of modern river sediments of the NNP territory, separate foci of natural and technogenic pollution were found, which is evidenced by the increased and abnormal values of the content of the studied trace elements. This indicates an unfavorable geochemical situation within the NNP for the study of natural processes.

Geochemical study of the territory of nature protected site as natural sample area, to a lesser extent disturbed by technogenic changes, is just beginning. Such studies pose the task, first of all, to identify the scale and types of technogenic and geochemical changes and most importantly - the establishment of the geochemical background, spreading and migration of chemical elements, the nature of natural geochemical reactions, the interrelationships of elements in the systems rock - river water - alluvial sediments - soil - plant, characteristics of geochemical conditions of the environment as a natural reference environment of the biofund genepool (Ladonin, 1995, 2002).

General patterns of spreading of the main chemical elements in soil-forming rocks and soils. Significant areas of the territory of the NNP "Tsumanska Pushcha", as noted above, are composed of water-glacial sediments.
They are the main soil-forming rocks. In areas where thin layers of these loose sands and sandy loams are underlain by chalk-marl rocks, the last ones can also be considered as soil-forming, and their influence on the formation of the geochemical background of landscapes is significant. The soil-forming rocks of the southern part of the study area are loess-like loams (Tessier at al., 1979; Vodyanitsky, 2005, 2009; Zayed at al., 2003).

Table 2 shows the average values of the main macroelements in the common soils of the NNP territory. A high content of silica is characteristic of Soddy slightly podzolic sandy soils. The main carrier of silica in the aforementioned soils is quartz. $\mathrm{SiO}_{2}$ is contained in feldspar, plagioclase, white mica, clay minerals in smaller amount.

The uneven spreading of $\mathrm{Al}_{2} \mathrm{O}_{3}$ over genetic bedding rocks is affected by the mechanical composition of the soil. The sporadic nature of the $\mathrm{Al}_{2} \mathrm{O}_{3}$ content is obviously associated with the insignificant migration of aluminum in the form of organo-mineral compounds. Basic alumina carriers in soils are feldspar, white mica and biotite in sandy-silt fractions. Very small percentage of $\mathrm{Al}_{2} \mathrm{O}_{3}$ is accounted for by minerals of the heavy fraction (amphibole, garnet, disthene, staurolite, etc.) (Bakker at al.,1997; Baron at al., 2006; Bartlett at al., 1979; Lubben at al.,1991).

An uneven spreading of iron oxide with genetic soil bedding rocks was also revealed. The acidic reaction of 
most types of soils promotes migration from humus-eluvial bedding rocks and accumulation in iluvial bedding rocks in the form of brown ferruginous accumulations. All studied soil types are characterized by an increase in content of iron oxide in humus bedding rock, which is due to the presence of organic matter.

Average chemical composition (macroelements) of soils in the NNP territory, \% on absolutely dry weight

\begin{tabular}{|c|c|c|c|c|c|c|c|}
\hline Soil & $\mathrm{SiO}_{2}$ & $\mathrm{Fe}_{2} \mathrm{O}_{3}$ & $\mathrm{Al}_{2} \mathrm{O}_{3}$ & $\mathrm{CaO}$ & $\mathrm{MgO}$ & $\mathrm{Na}_{2} \mathrm{O}$ & $\mathrm{K}_{2} \mathrm{O}$ \\
\hline Sod-slightly podzolic sandy on water-glacial sands & 95.15 & 0.79 & 3.35 & 0.28 & 0.15 & 0.39 & 1.15 \\
\hline Sod-weak (medium) - podzolic sandy on water glacial sands & 85.95 & 1.68 & 5.97 & 0.69 & 0.48 & 0.70 & 1.66 \\
\hline Sod-weak (medium) - podzolic sandy on loess-like loams & 81.98 & 2.42 & 7.68 & 0.79 & 0.77 & 0.89 & 2.34 \\
\hline Soddy carbonate light loam on loess-like loam & 71.43 & 2.86 & 9.56 & 2.52 & 1.54 & 0.82 & 2.11 \\
\hline Alluvial layered sandy loam on alluvial sands & 87.78 & 1.42 & 3.46 & 0.51 & 0.40 & 0.43 & 0.89 \\
\hline Low-power degraded peat bog & 2.64 & 1.42 & 0.78 & 3.82 & 0.41 & 0.08 & 0.07 \\
\hline Average in soils according to Vynogradov & 1.22 & 0.31 & 0.51 & 0.49 & 0.63 & 0.75 & 0.31 \\
\hline
\end{tabular}

Light texture soils are characterized by a relatively uniform spreading of iron with a soil profile. A slight increase in the content with depth is explained by high filtration capacity of these soils and the removal of iron by atmospheric precipitation from the upper soil bedding rocks to greater depth (Dmytruk, 2008).

In soils, iron is a part of some minerals confined to different particle size fractions. Its main mass is concentrated in the clay part, consisting mainly of hydromica. Insignificant iron content is included in the composition of the heavy fraction minerals: magnetite, black mica, amphibole, titanic iron ore, etc. (Glazovskaya, 1990).

Wide fluctuations in the content of calcium oxide are observed in NNP soils (up to $42 \%$ ). Increased concentrations are recorded for peatlands and Soddy calcareous light loam soils on loess-like loams and waterglacial sediments. The maximum concentration of $\mathrm{CaO}$ is characteristic of the iluvial soil bedding rocks.

Calcium in the studied soils is connected with plagioclases, clay minerals and minerals of heavy fractions (amphibole, tourmaline, pyroxene, etc.). The main part of it is caused by carbonates, particularly in transition soil bedding rocks.

Spreading of microelements in genetic bedding rocks of the main soil types of the NNP is determined by a wide variability. In sod slightly podzolic sandy soils accumulation of microelements is observed mainly in the upper humus part of the profile. In the studied sections there are two types of spreading of microelements: the accumulation of elements in organic bedding rocks with a gradual decrease in the concentration in the lower part of the profile and the spreading of the eluvial-illuvial type. The first type is characterized by an increasing spreading of $\mathrm{Zn}, \mathrm{Pb}$, and the second one - $\mathrm{Co}, \mathrm{Ni}, \mathrm{Cu}, \mathrm{Mn}$.

The maximum concentration of $\mathrm{Pb}, \mathrm{Cu}, \mathrm{Zn}$ in light gray light loam soils on loess-like loams is confined to the upper part of the soil profile; $\mathrm{Ni}, \mathrm{V}$ - to the transition and lower parts. Transient bedding rock is obviously the area of removal elements. In the layer of light gray soils (sampling point № 8-19), which is located in area of the former hunting grounds "Batozharnia", the maximum concentration of elements is confined to the transitional bedding rock.

In sod low-medium-podzolic sandy soils with depth there is an increase of the content of $\mathrm{Si}, \mathrm{Na}, \mathrm{K}, \mathrm{Mg}$ and $\mathrm{Ca}$, as well as the $\mathrm{pH}$ of the soil solution and a decrease $-\mathrm{Mn}, \mathrm{Ti}, \mathrm{Al}$. It turns out that there is a zone of leaching in the humus-eluvial bedding rocks (HE) and the accumulation in the first from the surface mineral, transitional to the rock, iluvial bedding rock (IR) of $\mathrm{Al}$ and $\mathrm{Fe}$ oxides.

In soddy-calcareous soils, the concentration of $\mathrm{Si}$, Te, $\mathrm{Al}$, $\mathrm{Mn}, \mathrm{K}$ decreases with depth, while $\mathrm{Ca}, \mathrm{Mg}$ increases. The division of the profile of soddy-carbonate light loamy soils into silicate and carbonate parts has a significant effect on the vertical spreading of microelement. Most of microelements accumulate in the upper silicate part of the profile.
Spreading of microelements in soils is inherited from the composition of soil-forming rocks. The main factors in the spreading of microelements in soils are organic matter, clay minerals and acid-base conditions. Analysis of microelements correlations nature with the physicochemical parameters of soils shows that in sod-carbonate light loamy, sod low-podzolic sandy and light gray light loam soils most microelements, as well as $\mathrm{Ti}, \mathrm{Mg}$, Al correlate positively with the content of dusty and silty fractions and organic matter. This is due to the strong connection of microelements with organo-mineral complexes of soils.

Spreading of soil-forming elements over the genetic bedding rocks of the studied soil types is subject to general tendency of concentration respreading: decrease in the content along the profile of $\mathrm{Te}, \mathrm{Fe}, \mathrm{Mn}$ and increase in $\mathrm{Ca}$ and $\mathrm{Mg}$.

An important factor contributing to increase in the content of these elements in upper part of the soil profile is the increased content of clay mineral particle size fractions and organic matter. Another reason is the carbonate content of the soil-forming rocks, which provides a change in acidbase conditions in the lower bedding rocks of soil profiles.

There are relations between spreading of soil chemical elements and their particle size spreading. In Soddy slightly podzolic sandy loam soils, an increased content of $\mathrm{Si}, \mathrm{Na}$ was recorded, in Soddy gley sandy loamy soils - Al, Fe, in Soddy slightly podzolic sandy soils with a significant content of silty fractions - $\mathrm{Ca}$, Mg.

Content of toxic elements in the landscapes of National Natural Park "Tsumanska Pushcha". It has been established that the indicators of the accumulation of heavy metals in soils of the NNP are significantly higher than average data for Kivertsevski district of the Volyn region.

Anthropogenic impact, in addition to agricultural activities, is associated here with large enterprises, in particular PJSC "Tsuman", LLC "Tanforan", LLC "Kaminskiy Timber and Venuses", LLC "Ukrlesservice", spontaneous dump of Tsumansky production department of housing and communal services p.g.t. Tsuman and Kadysche village), p.g.t. "Renaissance", PAF "Vistula", HK "Lutskvodokanal", etc.

Wastes of enterprises are substances of I - IV classes of danger. In particular, waste containing aluminum, vanadium, chromium and their compounds, lead (including Batteries for storage purposes or broken ones), iron carbonyls, etc.

Most of the studied HM exceeds the regional geochemical background. Migration and spreading of each metal along the profile of Soddy weakly - medium podzolic soils has its own specifics. Greatest accumulation of copper and zinc occurs in forest litters, and in mineral part of the profile it has a weakly expressed eluvial-iluvian character. Content of nickel, cobalt and manganese increases with depth of its accumulation in soil, which are characteristic of the chemical composition of glacial sediments (Lubben et al., 1991; Sauerbeck et al., 1991). 
It is noted that the amount of chromium, manganese and cobalt is higher in soil-forming rocks than in forest litters. Spreading along the profile of chromium, no regularities were found. The average HM content in the main soil types of the NNP territory is presented in Tables 3 and 4.

Table 3

Average HMs indicators in genetic bedding rocks of soil, most typical for the territory of NNP

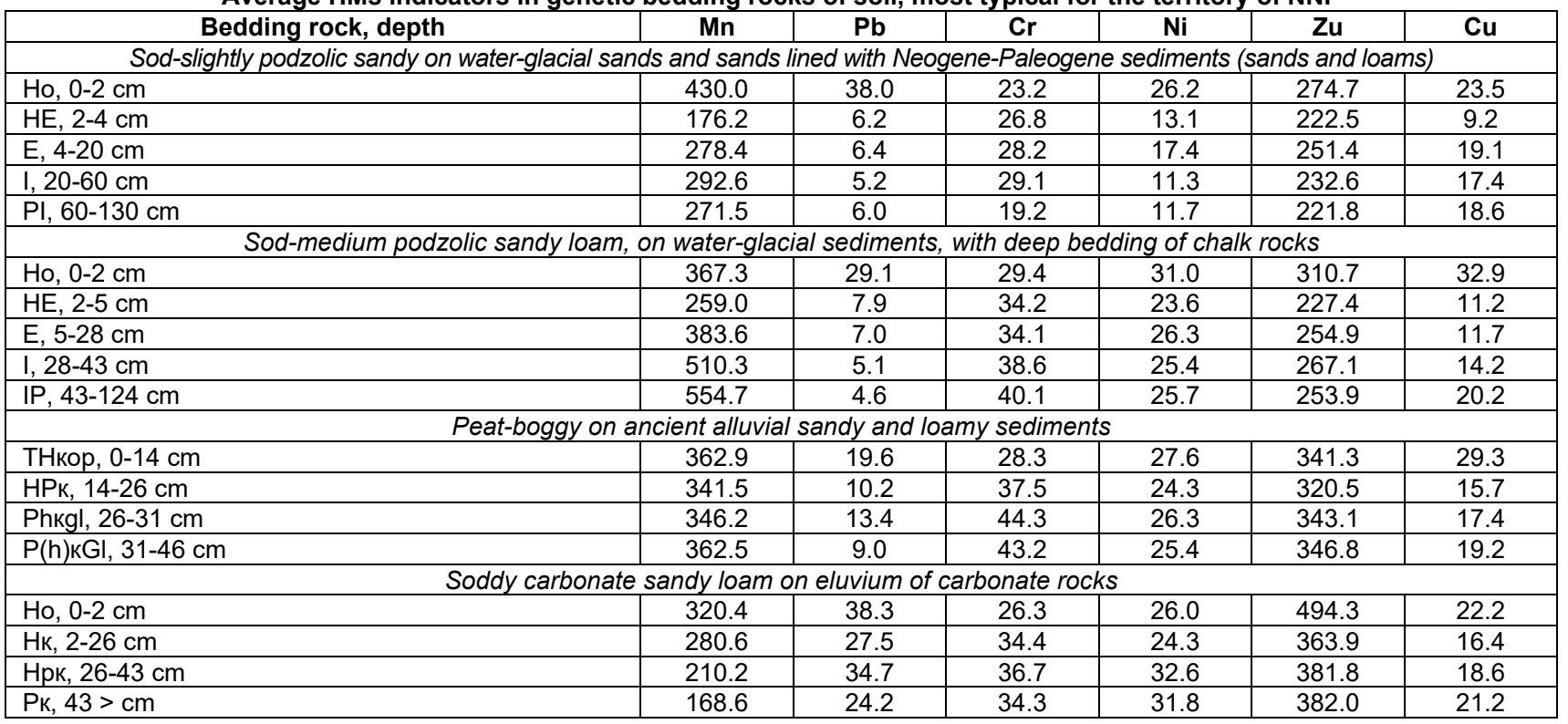

Total content of micronutrients in the soils of NNP

\begin{tabular}{|c|c|c|c|c|c|c|}
\hline \multirow{3}{*}{ Element } & Average values & Limits of oscillation & \multirow{3}{*}{$\mathbf{K}_{\mathrm{Ci}}$} & \multirow{3}{*}{$\begin{array}{c}\text { Background } \\
\text { values }\end{array}$} & Average values & limits of oscillation \\
\hline & & $\mathrm{gg} / \mathrm{kg}$ & & & \multicolumn{2}{|c|}{$\mathrm{mg} / \mathrm{kg}$} \\
\hline & \multicolumn{2}{|c|}{ Content of gross forms } & & & \multicolumn{2}{|c|}{ Content of mobile forms } \\
\hline Mn & 420 & $8.1-830$ & 1.06 & 395 & 0.89 & $0.27-1.9$ \\
\hline $\mathrm{Cr}$ & 30.4 & $5.2-60.8$ & 0.7 & 39 & 0.48 & $0.33-0.9$ \\
\hline $\mathrm{Ni}$ & 25.5 & $6.3-50.7$ & 2.1 & 12 & 0.8 & $0.6-1.6$ \\
\hline Zn & 350 & $60.3-700$ & 5 & 42 & 1.1 & $0.5-2.1$ \\
\hline $\mathrm{Cu}$ & 25.4 & $6.5-50.4$ & 3.1 & 8 & 1.7 & $0.9-3.4$ \\
\hline $\mathbf{P b}$ & 30.5 & $6.4-60.5$ & 2.7 & 11 & 0.6 & $0.38-1.2$ \\
\hline
\end{tabular}

By gross content of micronutrients in soil we can arrange the following series of geochemical: $\mathrm{Zn}>\mathrm{Cu}>\mathrm{Pb}>\mathrm{Ni}>\mathrm{Mn}>\mathrm{Cr}$. Accumulation of lead in forest litters up to $2-3$ LOC is clearly traced.

Obtained data about accumulation of heavy metals in soils of the NNP territory are of significant importance, since they are the basis for identifying spatial patterns of soil pollution and establishing the local geochemical background.
Most of heavy metals spread unevenly in the soil cover. High values of the coefficient of variation $(\mathrm{V})$ are more than $34 \%$ typical for heterogeneous set of data on concentration of all studied HMs (Table 5). The highest rate of variation was found for lead concentration $-170 \%$, and the lowest values were obtained for content of chromium $-34 \%$ and zinc $-36 \%$.

Table 5

Statistical indicators of HMs content in NNP soils, $\mathrm{mg} / \mathrm{kg}$

\begin{tabular}{|c|c|c|c|c|c|c|}
\hline Element (background) & Arithmetic mean & Geometric mean & Maximum value & Minimal value & $\boldsymbol{\sigma}$ & $\mathbf{V}, \%$ \\
\hline $\mathbf{M n ~ ( 3 9 5 )}$ & 420 & 81.9 & 830 & 8.1 & 341.0 & 81 \\
\hline $\mathbf{P b}$ (11) & 30.5 & 19.6 & 60.5 & 6.4 & 52.1 & 170 \\
\hline $\mathbf{C r}$ (39) & 30.4 & 8.1 & 60.8 & 5.2 & 10.5 & 34 \\
\hline $\mathbf{N i ~ ( 1 2 )}$ & 25.5 & 17.8 & 50.7 & 6.3 & 11.6 & 45 \\
\hline $\mathbf{Z n ~ ( 4 2 )}$ & 350 & 205.9 & 700 & 60.3 & 76.7 & 36 \\
\hline $\mathbf{C u}$ (8) & 29.4 & 19.8 & 60.4 & 6.5 & 21.4 & 72 \\
\hline
\end{tabular}

To characterize the average content of heavy metals in the soils of the NNP, the arithmetic and geometric mean values were calculated. This is due to the fact that the indicators of the concentration of elements in soils vary greatly and do not obey the law of equable spreading. As a result, arithmetic mean strongly depends on the presence of small number of samples with higher levels of elements. In such cases, it would be more correct to use geometric mean to estimate the HM content in the soil. Geometric mean $\mathrm{N}$ of numbers is equal to the root of the Nth degree from the product of these numbers, in this case - product of all obtained values of the content of a particular chemical element. Such an indicator is always less than arithmetic mean, in terms of its value, large deviations and fluctuations between individual values in the studied set of indicators are much less affected.

High value of the standard deviation $(\sigma)$ is an indication of the average values of sporadic. Minimum standard deviation was obtained for chromium concentrations -30.5 , and maximum for manganese 341.0 . 
Table 5 also presents characteristics of the average values of the HM content in soils of the NNP. The average content of all studied HMs exceeds their regional background values.

Lead. Lead usually accumulates in fractions $<0.01 \mathrm{~mm}$. Its main concentrators are clay minerals and associated impurities. Gross $\mathrm{Pb}$ content in NNP soils averages $30.5 \mathrm{mg} / \mathrm{kg}$ almost does not exceed the LOC (32 mg/kg), but 3 times higher than regional background $(11 \mathrm{mg} / \mathrm{kg})$. Indicators range from $6 \mathrm{mg} / \mathrm{kg}$ in sod-slightly podzolic gley sandy soils to $60.5 \mathrm{mg} / \mathrm{kg}$ in Soddy calcareous light loamy soils. In its mobile form, lead is on average at $0.4 \mathrm{mg} / \mathrm{kg}$, the fluctuation range is $0.06-1.9 \mathrm{mg} / \mathrm{kg}$.

However, the geometric mean value calculated by us is $19.6 \mathrm{mg} / \mathrm{kg}$, which is significantly lower than the LOC. Elevated lead content is characteristic of the soils of the western part of the park with developed economic sector and accordingly large anthropogenic load on the soil cover. Significant lead accumulation was found in soils of territories characterized by an increased density of road traffic (Tsuman, Zhuravychi, Kivertsi, Sokyrychi). In places of increased exposure to vehicles (roadsides), high levels of lead accumulation $(46-52 \mathrm{mg} / \mathrm{kg}$ ) are probably due to the use of tetraethyl lead in gasoline until recently. The maximum value of lead content is observed on the lands of the park adjacent to the lake (point № 25) $-59.8 \mathrm{mg} / \mathrm{kg}$. It should be noted that within the military unit to the north-west of the village Zhuravychi there is a technical zone. In the soils of this territory, high values of lead content were also found $-42-57 \mathrm{mg} / \mathrm{kg}$ (point № 23). Within the 15th quarter of Horynskii and 49th quarter of the Lopatenskii forestry, lead content in soils is also increased and amounts up to $42.6 \mathrm{mg} / \mathrm{kg}$ (point № 37). With distance from center of the military unit, a noticeable decrease in concentration of lead in soils is observed.

Least slightly contaminated with lead, in comparison with other parts of the park, is the floodplain of the river Rudka, composed of sandy and loamy alluvium with peat-bog soils and peat bogs under the black alder forests and bog-grass meadows, where its content does not exceed $5 \mathrm{mg} / \mathrm{kg}$. Thus, the studies carried out showed that the highest lead contamination in soils was detected on lands of the category of economic use $(55.3 \mathrm{mg} / \mathrm{kg})$ and zone of stationary recreation (up to $60 \mathrm{mg} / \mathrm{kg}$ ). It is important to note that on lands of economic use, the concentration of lead in some areas increases with depth and can reach 3-4 LOC in soil bedding rocks close to the parent rock. Also, high values were found for the lands of the protected area, especially for the test plots with Soddy calcareous light loam soils on loess-like loams. Here, lead content exceeded the LOC in only one test plot $(57.3 \mathrm{mg} / \mathrm{kg})$.

Barrier role of forest litters is clearly traced, preventing entry of lead into the underlying ground bedding rocks.

Zinc. Average zinc content in NNP soils is $210 \mathrm{mg} / \mathrm{kg}$, which exceeds the background values $(42 \mathrm{mg} / \mathrm{kg})$ and the maximum concentration limit $(150 \mathrm{mg} / \mathrm{kg})$. Content of mobile forms of zinc ranges from 0.5 to $2.1 \mathrm{mg} / \mathrm{kg}$. Humus bedding rock is characterized by more intensive removal of mobile forms of zinc.

Content of gross forms of zinc in soils ranges from $60.3 \mathrm{mg} / \mathrm{kg}$ to $700 \mathrm{mg} / \mathrm{kg}$. The highest concentration is characterized by sod-slightly podzolic sandy soils on waterglacial sands $(620-700 \mathrm{mg} / \mathrm{kg})$. The maximum value was recorded on territory of the military unit on the north-west of the village Zhuravichi (point № $136-670.5 \mathrm{mg} / \mathrm{kg}$ ). On lands of economic use, maximum concentration of zinc $450-680 \mathrm{mg} / \mathrm{kg}$ - was found in soil samples taken in quarter 55 on sampling plot № 81 and in the "Hrud" tract. On rural lands, the maximum value of zinc, which reaches $321.6 \mathrm{mg} / \mathrm{kg}$, was found in the village Yaromel (point № 2619). The highest zinc content was found to the left of the road to Tsuman (point № 35-19) - $700.6 \mathrm{mg} / \mathrm{kg}$, where an unauthorized household landfill operates. On lands of the protected area this element is less than $60 \mathrm{mg} / \mathrm{kg}$ in soil content. Thus, in the NNP, including protected areas, there is a tendency to accumulate zinc. Exceptions are denudation interfluve lowland plains, composed of low-strength waterglacial sands and sandy loams, with shallow marls and chalks, with sod-podzolic, sod-gley and humus-carbonate clay-sandy and sandy soils ( $\mathrm{Zn}$ content up to $20 \mathrm{mg} / \mathrm{kg}$ ) (Kabata-Pendias at ai., 2007).

It is known that zinc is easily adsorbed by clays and colloids of organic matter. It has different complexing ability depending on the composition of organic matter. In wetlands, $41 \%$ of zinc and $13 \%$ of fulvic acids are bound to the humic acid fraction. Because humic and fulvic acids differ slightly in structure and properties, their ability to form complexes with metals is different. Based on the study of humates and fulvates of the park soils, it was also found that zinc mainly forms complexes with humic acids, but the complexing ability of this element with fulvic acids is much lower (Kabata-Pendias et al., 1989).

Nickel. Average nickel content in the organogenic and mineral bedding rocks of the soils of the NNP is average $25.5 \mathrm{mg} / \mathrm{kg}$, however, its concentration varies widely - from $3 \mathrm{mg} / \mathrm{kg}$, in sod-slightly podzolic sandy (point № 20-19) up to $40-50 \mathrm{mg} / \mathrm{kg}$ in turf carbonate light loam soils (point № 25-19) and lowland peatlands (point № 22-19). In the studied soils, nickel is contained exclusively in thin fractions $(<0.01 \mathrm{~mm})$. In general, its average concentration in the soils of NNP is 1.5 above the background values.

The average content of nickel in mobile form in the mineral bedding rocks of the studied soils is at the level of $0.8 \mathrm{mg} / \mathrm{kg}$, which averages $22 \%$ of its total content, which characterizes the heterogeneous supply of soils in this area with mobile nickel. Organogenic bedding rocks of mobile nickel contain up to $1.3 \mathrm{mg} / \mathrm{kg}$. With depth, the content of mobile Nickel decreases to $0.29-0.34 \mathrm{mg} / \mathrm{kg}$. We calculated the geometric mean value $-17.8 \mathrm{mg} / \mathrm{kg}$. Approximately the background concentration level is $12 \mathrm{mg} / \mathrm{kg}$, but the LOC level is higher and equal to $20 \mathrm{mg} / \mathrm{kg}$. In general, on territory of the NNP there is a tendency to accumulate nickel in soils of the floodplain of the rivers Kormyn and Rudka, including territory of the old peat extraction $(37-48 \mathrm{mg} / \mathrm{kg})$. The research revealed only one point (number 31-19) of nickel which is $50 \mathrm{mg} / \mathrm{kg}$. The increased concentration of nickel was recorded in soils of permanent test areas (points №№ 40-19, 58-19) and in territory of an unauthorized landfill (point № 64) $-47.1 \mathrm{mg} / \mathrm{kg}$. On the lands of rural development, as well as on lands of regulated recreation there are no values exceeding the maximum allowable concentration. However, level of background values of nickel content is exceeded in most soil samples, regardless of land use category.

Chromium. Chromium is concentrated in small fractions with a maximum content in fractions $<0.01 \mathrm{~mm}$. In the fractions of $0.25-0.1$ and $0.1-0.075 \mathrm{~mm}$ chromium is not fixed or contained in small quantities $(0.001 \%)$. In studied soils, chromium is part of the organo-clay-iron aggregates (in fraction of $0.075-0.01 \mathrm{~mm}$ ), and also occurs in the form of sorbed cations (clay fractions). The average value of chromium in soils of NNP is $30.4 \mathrm{mg} / \mathrm{kg}$, which is 3 times less than the LOC, and below the level of the regional background $(39 \mathrm{mg} / \mathrm{kg})$. Concentration of chromium in soils varies from 5.2 to $60.8 \mathrm{mg} / \mathrm{kg}$, which does not exceed the maximum concentration limit. The results of research show 
that in the soils of NNP there is a tendency to the accumulation of chromium in sod-weak and sod-mediumpodzolic sandy soils on water-glacial sands. Increased content is characteristic of sod carbonate light loam soils developed on loess-like loams. High levels of content $(37-40 \mathrm{mg} / \mathrm{kg})$ were also observed for sod podzolic gley sandy soils ( $37-40 \mathrm{mg} / \mathrm{kg}$ ) and lowland peatlands (up to $50 \mathrm{mg} / \mathrm{kg}$ ).

The maximum rate was observed in the $23 \mathrm{rd}$ quarter of Horynskiy forestry (point № 47 ) $-49 \mathrm{mg} / \mathrm{kg}$. The increased concentration of chromium was found in low-power peatlands in floodplain of the Rudka River (point № 6-19) $45.2 \mathrm{mg} / \mathrm{kg}$. Indicators exceeding the regional background of the content of this element are noted in $37 \%$ of number of soil samples taken on lands of the economic zone and stationary recreation.

High level of chromium concentration in forest litters of sod-slightly podzolic sandy soils on water-glacial sands is $46.2 \mathrm{mg} / \mathrm{kg}$, which exceeds the background values by 3-4 times. The mineral horizons of these soils are also characterized by a high content of chromium $-54.2 \mathrm{mg} / \mathrm{kg}$, which is a consequence of its significant content in the soilforming rock. Slightly lower concentration of chromium was found in the mineral horizons of sod gley sandy soils $21.5 \mathrm{mg} / \mathrm{kg}$ and sod podzolic gley sandy soils $-30.2 \mathrm{mg} / \mathrm{kg}$.

The amount of mobile chromium in the mineral bedding rocks of soils averages $0.48 \mathrm{mg} / \mathrm{kg}$, which is $42 \%$ of its total content. The range of fluctuations is very wide -0.33 $0.9 \mathrm{mg} / \mathrm{kg}$.

Manganese. According to ICP-AES analysis, the content of $\mathrm{Mn}$ in the soils of the NNP ranges from 8$800 \mathrm{mg} / \mathrm{kg}$. The average concentration is $420 \mathrm{mg} / \mathrm{kg}$, with regional background values of $395 \mathrm{mg} / \mathrm{kg}$. Manganese in the soils of the territory is in the form of isomorphic impurities in clay, clay-iron aggregates of fraction $0.075-$ $0.01 \mathrm{~mm}$ or in clay minerals of fine fractions and in the absorption complex.

It is established that on the territory of NNP separate territories with dominance of sod-weakly podzolic sandy (tract "Hrud") and alluvial layered sandy soils (quarter 4 of integrated agricultural production center) depleted in manganese, fluctuation limits are of $30-100 \mathrm{mg} / \mathrm{kg}$. Maximum concentration $(700-800 \mathrm{mg} / \mathrm{kg}$ ) is typical for light gray loamy soils (former hunting grounds "Bazhotarnia"). High indicators of manganese content were recorded in the mineral horizons of meadow-swamp and peat-swamp soils $(650-670 \mathrm{mg} / \mathrm{kg})$. The selected samples are enriched with organic matter. They also have a high proportion of mobile forms of manganese - up to $1.9 \mathrm{mg} / \mathrm{kg}$, while on average they are about $0.89 \mathrm{mg} / \mathrm{kg}$.

The increased content of manganese in the surface horizon of the soil in the NNP is due, in our opinion, to the fact that manganese is a biophilic element involved in redox processes. In this regard, there is its biogenic accumulation in the surface bedding rocks of the soil, in particular, in the forest litter, formed from plant precipitation. In most samples, amount of manganese is above the background level, but below the LOC level, regardless of the category of nature. High levels of manganese in the park are recorded locally, which is not dangerous because the element is not a toxic pollutant. However, at high concentrations, its phytotoxicity is detected (Anitipov at al., 2002).

In the studied soils, manganese is found in clay-iron and clay aggregates of fraction $0.074-0.01 \mathrm{~mm}$, in clay minerals of fine fractions and in the absorbing complex.

Copper. Average copper content in NNP soils is $29.4 \mathrm{mg} / \mathrm{kg}$, which is three times higher than the regional background value $(8 \mathrm{mg} / \mathrm{kg})$. Geometric mean value of the copper concentration in soils is $19.8 \mathrm{mg} / \mathrm{kg}$, which also exceeds the background value and is close to LOC level $(33 \mathrm{mg} / \mathrm{kg})$. Copper is fixed in all fractions of soils of the territory. The maximum values are typical for the fraction $<0,01 \mathrm{~mm}$. There is higher concentration in fractions from samples of transitional bedding rock, slightly less - in humus bedding rock.

It was found that in soils of the studied area copper concentrations have significant fluctuations - from $10 \mathrm{mg} / \mathrm{kg}$ in sod-slightly podzolic gley sandy to $60 \mathrm{mg} / \mathrm{kg}$ in lowland peatlands. According to research, the largest amounts of copper are found in soils on forest deposits and on average their content in soils of the park is $19-25 \mathrm{mg} / \mathrm{kg}$. Maximum concentrations of copper were also recorded in light gray loamy, sod carbonate and sod podzolic gley sandy soils $(35-55 \mathrm{mg} / \mathrm{kg})$. Sod-slightly podzolic sandy soils are characterized by low copper content $(5-6 \mathrm{mg} / \mathrm{kg})$. According to the spatial spreading of copper in soils, there is a noticeable tendency for the element to accumulate in alluvial layered sandy soils and low-power peatlands located in the floodplain of the Rudka River. The maximum concentration limit was exceeded in $27 \%$ of soil samples. It should be noted there are increased indicators of copper content in sod-medium-podzolic sandy soils in 1-2 quarters of Horynskiy forestry (point № 56) $-51.9 \mathrm{mg} / \mathrm{kg}$ and in sodslightly podzolic sandy soils integrated agricultural production centre "Druzhba", sq. 10 (Davydiv Forest, point № 35) - $55.5 \mathrm{mg} / \mathrm{kg}$. Concentration of copper in the protected area does not exceed $10-12 \mathrm{mg} / \mathrm{kg}$. Content of mobile copper in the mineral bedding rocks of soils averages $1.7 \mathrm{mg} / \mathrm{kg}$. Low concentration of mobile forms of copper is characteristic of meadow soils $-0.9 \mathrm{mg} / \mathrm{kg}$. The highest values of mobile copper were found in sod-slightly podzolic sandy-sandy soils of $3.2 \mathrm{mg} / \mathrm{kg}$, which is about $73 \%$ of the total copper content.

Conclusions. In spatial terms, the landscapegeochemical structure of NNP and adjacent territories are represented by calcium, calcium-carbonate, carbotate-gley, acidic calcium geochemical landscape classes.

Analysis of the content of heavy metals in the soils of the territory showed its non-uniform spreading and dependence on the available sources of anthropogenic impact. The highest concentrations of manganese and chromium are found in soils developed on loess sediments, nickel and copper on glacial sediments.

The main direction of further research should be the study of the spreading of macro- and microelements in various genetic types of soils; determination of the reference content of elements in geochemical landscapes to establish the intensity of migration and nature of the spreading of elements; carrying out biogeochemical zoning. The data on the spreading of pollutants in soil cover of NNP territory landscape complexes are presented; it is an example that illustrates the relevance of such an analysis, especially for protected areas.

The promising tasks for further development of this direction is the study of the distribution of chemical elements in the "soil-plant" system of NNP territory; regularities of composition, development and distribution of vegetation cover depending on the geochemical parameters of the soil; concentration of chemical elements in some types of plants; seasonal dynamics of the content of elements; pathological and specific plant diseases caused by the geochemical features of the landscape; adaptation of plants to new geochemical environmental factors. 
Список використаних джерел

Анитипов, М.А., Голицын, М.С. (2002). Подвижные формы тяжелых металлов в почвах и грунтах зоны аэрации. Геоэкологические исследования и охрана недр. Москва: ООО "Геоинформцентр".

Водяницкий, Ю.Н. (2009). Тяжелые и сверхтяжелые металлы и металлоиды в загрязненных почвах. Москва: Почвенный институт им. В.В. Докучаева.

Водяницкий, Ю.Н. (2005). Изучение тяжелых металлов в почвах. Москва: Почвенный институт им. В.В. Докучаева.

Глазовская, М.А. (1990). Принципы классификации почв по опасности их загрязнения тяжелыми металлами. Биол. науки, 9, 38-52.

Дмитрук, Ю.М. (2008). Використання окремих підходів при аналізі еколого-геохімічного статусу ґрунтів різних типів. Ґрунтознавство, 9, 41-49.

Жовинський, Е.Я., Кураєва, І.В. та ін. (2012). Еколого-геохімічні дослідження об'єктів довкілля України. Київ: Альфа-реклама.

Жовинський, Е.Я., Кураєва, І.В., Самчук, А.І. та ін. (2005). Важкі метали у ґрунтах заповідних зон України. Київ: Логос.

Кабата-Пендиас, А., Пендиас, Х. (1989). Микроэлементы в почвах и растениях. Москва. Мир.

Ладонин, Д.В. (2002). Соединения тяжелых металлов в почвах - про-

блемы и методы изучения. Почвоведение, 10, 682-692.

Ладонин, Д.В. (1995). Влияние техногенного загрязнения на фракционный состав меди и цинка в почвах. Почвоведение, 10, 1299-1305.

Adriano, D.C. (1986). Trace elements in the terrestrial environment. New

York: Springer. Chap. 9

Bakker, D.J., de Vries, W. (1997). Effect-based approaches to assess the risks of persistent organic pollutants to soils. Background document for the workshop on critical limits and effect-based approaches for heavy metals and POP's. Bad Harzburg, Germany.

Baron, S., Carignan, J., Ploquin, A. (2006). Dispersion of heavy metals (metalloids) in soils from 800-year old pollution (Mont-Lozere, France). Environ. Sci. Technol., 40, 5319-5326.

Bartlett, R.J., James, B.R. (1979). Behavior of chromium in soils: Oxidation. Journal of Environmental Quality, 8, 31-35.

Zayed, A.M., Terry, N. (2003). Chromium in the environment: Factors affecting biological remediation. Plant and Soil, 249, 139-156.

Tessier, A., Campbell, P., Bisson, M. (1979). Sequential extraction procedure for the speciation of the particulate trace metals. Anal. Chem., 51, 844-851.

Stoops, G., Marcelino, V. Mees, F. (2010). Interpretation of Micromorphological Features of Soils and Regoliths. Elsevier Science.

Hodson, M.E. (2004). Heavy metals-geochemical bogey men? Environmental Pollution, 129, 341-343.

Kabata-Pendias, A., Mukherjee, A.B. (2007). Trace elements from soil to human. Berlin: Springer.

Lubben, S., Sauerbeck, D.R. (1991). The uptake and distribution of heavy metals by spring wheat. Water, Air and Soil Pollution, 57-58, 239-247.

Sauerbeck, D.R., Heir, A. (1991). The nikel uptake from different soil and prediction by chemical extractions. Water, Air and Soil Pollutions, 57-58, 861-874.

\section{References}

Adriano, D.C. (1986). Trace elements in the terrestrial environment. New York: Springer. Chap. 9
Anitipov, M.A., Golitsyn, M.S. (2002). Mobile forms of heavy metals in soils and soils of the aeration zone. Geoecological research and protection of mineral resources. Moscow: LLC "Geoinformcenter". [in Russian]

Bakker, D.J., de Vries, W. (1997). Effect-based approaches to assess the risks of persistent organic pollutants to soils. Background document for the workshop on critical limits and effect-based approaches for heavy metals and POP's. Bad Harzburg, Germany.

Baron, S., Carignan, J., Ploquin, A. (2006). Dispersion of heavy metals (metalloids) in soils from 800-year old pollution (Mont-Lozere, France). Environ. Sci. Technol., 40, 5319-5326.

Bartlett, R.J., James, B.R. (1979). Behavior of chromium in soils: Oxidation. Journal of Environmental Quality, 8, 31-35.

Dmytruk, Yu.M. (2008). The use of separate approaches in the analysis of ecological and geochemical status of soils of different types. Pedology, 9, 4149. [In Ukrainian]

Glazovskaya, M.A. (1990). Principles of soil classification according to the hazard of their contamination with heavy metals. Biol. Science, 9, 38-52. [in Russian]

Hodson, M.E. (2004). Heavy metals-geochemical bogey men? Environmental Pollution, 129, 341-343.

Kabata-Pendias, A., Mukherjee, A.B. (2007). Trace elements from soil to human. Berlin: Springer.

Kabata-Pendias, A., Pendias, H. (1989). Microelements in soils and plants. Moscow: Mir. [in Russian]

Ladonin, D.V. (1995). Influence of technogenic pollution on the fractional composition of copper and zinc in soils. Soil Science, 10, 1299-1305. [in Russian]

Ladonin, D.V. (2002). Compounds of heavy metals in soils - problems and methods of study. Soil Science, 10,682-692. [in Russian]

Lubben, S., Sauerbeck, D.R. (1991). The uptake and distribution of heavy metals by spring wheat. Water, Air and Soil Pollution, 57-58, 239-247.

Sauerbeck, D.R., Heir, A. (1991). The nikel uptake from different soil and prediction by chemical extractions. Water, Air and Soil Pollutions, 57-58, 861-874.

Stoops, G., Marcelino, V., Mees, F. (2010). Interpretation of Micromorphological Features of Soils and Regoliths. Elsevier Science.

Tessier, A., Campbell, P., Bisson, M. (1979). Sequential extraction procedure for the speciation of the particulate trace metals. Anal. Chem., 51, 844-851.

Vodyanitsky, Yu.N. (2005). Study of heavy metals in soils. Moscow: Soil Institute named after V.V. Dokuchaev. [in Russian]

Vodyanitsky, Yu.N. (2009). Heavy and superheavy metals and metalloids in contaminated soils. Moscow: Soil Institute named after V.V.Dokuchaeva. [in Russian]

Zayed, A.M., Terry, N. (2003). Chromium in the environment: Factors affecting biological remediation. Plant and Soil, 249, 139-156.

Zhovynskyi, E.Ya., Kuraeva, I.V. et al. (2012). Ecological and geochemical studies of environmental objects of Ukraine. Kyiv: "Alfa-reklama". [In Ukrainian]

Zhovynskyi, E.Ya., Kuraeva, I.V., Samchuk, A.I. et al. (2005). Heavy metals in soils of preserved areas of Ukraine. Kyiv: Lohos. [In Ukrainian] Надійшла до редколегії 19.12.2020

А. Сплодитель, канд. геогр. наук, докторант

E-mail: asplodytel@gmail.com;

Інститут геохімії, мінералогії та рудоутворення ім. М.П. Семененка НАН України,

просп. Акад. Палладіна, 34, м. Київ, 03680, Україна

\section{ЕКОЛОГО-ГЕОХІМІЧНА ОЦІНКА РОЗПОДІЛУ ТЕХНОГЕННИХ ЕЛЕМЕНТІВ НА ТЕРИТОРІЇ КІВЕРЦІВСЬКОГО НАЦІОНАЛЬНОГО ПРИРОДНОГО ПАРКУ "ЦУМАНСЬКА ПУЩА"}

Розглянуто особливості акумуляції та розподілу забруднювальних речовин у ландшафтах Кнпп "Цуманська Пуща" в умовах природних і техногенних геохімічних аномалій. Аналіз вмісту важких металів у ґрунтах території засвідчив неоднорідний розподіл та залежність від наявних джерел техногенного впливу. Проаналізовано масив даних та розраховано геохімічні коефіцієнти накопичення основних забруднювачів. Найвищі концентрації марганцю та хрому мають ґрунти, що розвинуті на лесових відкладах, а нікелю та міді - на воднольодовикових відкладах. Більшість досліджуваних важких металів перевищує регіональний геохімічний фон. За валовим вмістом у ґрунтах мікроелементи формують такий геохімічний ряд: $\mathrm{Zn}>\mathrm{Cu}>\mathrm{Pb}>\mathrm{Ni}>\mathrm{Mn}>\mathrm{Cr}$. Чітко простежується накопичення в лісових підстилках свинцю - до 2-3 ГДК.

Більшість важких металів у ґрунтовому покриві розподілені нерівномірно. Високі значення коефіцієнта варіації- понад 34 \% - характерні для неоднорідної сукупності даних щодо концентрацій всіх досліджуваних важких металів. Найвищий показник варіації виявлений для концентрації свинцю - 170 \%, найменші значення отримані для вмісту хрому - 34 \% і цинку - 36 \%. У вивчених ґрунтах спостерігається два типи розподілу мікроелементів: акумуляція елементів в органічних горизонтах з поступовим зменшенням кониентрації в нижній частині профілю та розподіл за елювіально-ілювіальним типом. Для першого типу характерний зростаючий розподіл - Zn, Рb, для другого - Co, $\mathrm{Ni}, \mathrm{Cu}, \mathrm{Mn}$.

Виконано еколого-геохімічну оцінку розподілу техногенних елеметів території КнПП "Цуманська Пуща" на основі порівняння техногенної геохімічної спеціалізації різних середовищ (вода, ґрунти тощо). Для оцінки ролі компонентів ландшафту в загальній геохімічній аномальності території запропоновано створювати сумарні еколого-геохімічні оцінки, що представляють суму значень коефіцієнтів концентрації полютантів в окремих компонентах.

Основним напрямом подальших досліджень має бути вивчення розподілу макро- та мікроелементів у різних генетичних типах ґрунтів; визначення еталонного вмісту елементів у геохімічних ландшафтах для встановлення інтенсивності міграції та характеру розподілу елементів; проведення біогеохімічного районування.

Ключові слова: валовий вміст, техногенні елементи, коефіцієнти накопичення. 
А. Сплодитель, канд. геогр. наук, докторант,

E-mail: asplodytel@gmail.com;

Институт геохимии, минералогии и рудообразования им. Н.П. Семененко НАН Украины,

просп. Акад. Палладина, 34, г. Киев, 03142, Украина

\section{ЭКОЛОГО-ГЕОХИМИЧЕСКАЯ ОЦЕНКА РАСПРЕДЕЛЕНИЯ ТЕХНОГЕННЫХ ЭЛЕМЕНТОВ НА ТЕРРИТОРИИ КИВЕРЦОВСКОГО НАЦИОНАЛЬНОГО ПРИРОДНОГО ПАРКА "ЦУМАНСКАЯ ПУЩА"}

Рассмотрены особенности аккумуляции и распределения загрязняющих веществ в ландшафтах КНПП "Цуманская Пуща" в условиях природных и техногенных геохимических аномалий. Анализ содержания тяжелых металлов в почвах территории показал неоднородное распределение и зависимость от имеющихся источников техногенного воздействия. Проанализированы массивы данных и рассчитаны геохимические коэффициенты накопления основных загрязнителей. Наиболее высокие концентрации марганца и хрома имеют почвы, развитые на лёссовых отложениях, никеля и меди - на водноледниковых отложениях. Большинство исследуемых тяжелых металлов превышает региональный геохимический фон. По валовому содержанию в почвах микроэлементы формируют следующий геохимический ряд: $\mathrm{Zn>Cu>Pb>Ni>Mn>Cr.} \mathrm{Четко} \mathrm{прослеживается} \mathrm{накопления} \mathrm{в} \mathrm{лесных} \mathrm{подстилках} \mathrm{свинца} \mathrm{-} \mathrm{до} \mathrm{2-3} \mathrm{Пдк.}$

Большинство тяжелых металлов в почвенном покрове распределены неравномерно. Высокие значения коэффициента вариации более $34 \%$ - характерные для неоднородной совокупности данных о концентрации всех исследуемых тяжелых металлов. Самый высокий показатель вариации обнаружен для концентрации свинца - 170 \%, наименьшие значения получены для содержания хрома - 34 \% и цинка - 36 \%. В изученных почвах наблюдается два типа распределения микроэлементов: аккумуляция элементов в органических горизонтах с постепенным уменьшением концентрации в нижней части профиля и распределение по элювиально-иллювиальному типу. Для первого типа характерно растущее распределение - $\mathrm{Zn}, \mathrm{Pb}$, для второго - Co, $\mathrm{Ni}, \mathrm{Cu}, \mathrm{Mn}$.

Выполнена эколого-геохимическая оценка распределения техногенных элеметов территории Кнпп "Цуманская Пуща" на основе сравнения техногенной геохимической специализации различных сред (вода, почвы и т.д.). Для оценки роли компонентов ландиафта в общей геохимической аномальности территории предложено рассчитать суммарную эколого-геохимическую оценку, что представляет сумму значений коэффициентов концентрации загрязнителей в отдельных компонентах.

Основным направлением дальнейших исследований должно стать изучение распределения макро- и микроэлементов в различных генетических типах почв; определение эталонного содержания элементов в геохимических ландшафтах для установления интенсивности миграции и характера распределения элементов; проведение биогеохимического районирования.

Ключевые слова: валовое содержание, техногенные элементы, коэффициенты накопления. 